Apidologie, 1988, 19 (3), 241-244

\title{
VARROA JACOBSONI DOES REPRODUCE IN WORKER CELLS OF APIS CERANA IN SOUTH KOREA
}

\author{
David DE JONG \\ Depto. de Genética Faculdade de Medicina, USP, 14.049 Ribeirão Preto-SP BRASIL
}

\begin{abstract}
SUMMARY
Contrary to previous reports from Sri Lanka and Indonesia of an inability of Varroa jacobsoni to reproduce on worker brood of it's original host, Apis cerana, successful reproduction in worker cells was found in Apis cerana colonies in South Korea.
\end{abstract}

\section{INTRODUCTION}

Varroa jacobsoni, an ectoparasitic bee mite, causes extensive damage to Apis mellifera colonies in much of the world, however the original host, Apis cerana is reported as little affected (DE JoNG et al. 1982).

Some of the factors which may contribute to the resistance of Apis cerana have been investigated. Peng et al. (1987) observed that Apis cerana workers rapidly attack and kill Varroa jacobsoni introduced into their colony. KoENIGER et al. $(1981,1983)$ reported that Varroa jacobsoni greatly prefers drone over worker brood, and only reproduces in the drone brood of Apis cerana colonies in Sri Lanka and Indonesia. In Apis mellifera the mites also prefer drone cells, but can reproduce effectively in both worker and drone cells. The capacity to reproduce in worker brood cells apparently emerges as an important adaptation to the new host, greatly increasing the potential of the mite populations for increase and also causing much greater damage to the worker bee populations, and therefore to the welfare and production capacity of mellifera colonies.

\section{MATERIAL AND METHODS}

During two visits to South Korea in 1986 and 1987, combs from five Apis cerana colonies from four apiaries located in four separate provinces were examined for Varroa jacobsoni infestations. Sealed brood 
cells were opened individually with the aid of a forceps and both the larva or pupa and the interior of the cell examined carefully for mites.

An evaluation of mite reproduction was made for all mites found associated with bee pupae. The categories distinguished were : original females, new adult females, female deutonymphs, female protonymphs and males (not discriminated), and eggs. Mites in cells containing bec larvae would not have had time to reproduce and therefore the reproduction was not evaluated.

\section{RESULTS}

Drone brood cells were much more frequently infested than the worker cells $(\mathrm{P}<.001$, chi square test $)$. Varroa jacobsoni reproduced on all of the infested drone pupae and on the few infested worker pupae encountered in these samples (Table 1).

TABL. 1. - Reproduction of Varroa jacobsoni in worker and drone brood cells of Apis cerana

\begin{tabular}{l|c|c|c|c|c|c|c|c}
\hline \hline & $\begin{array}{c}\text { Total } \\
\text { cells }\end{array}$ & $\begin{array}{c}\text { Cells } \\
\text { infested }\end{array}$ & $\begin{array}{c}\text { Infested } \\
\text { pupae }\end{array}$ & $\begin{array}{c}\text { Original } \\
\text { females } \\
\text { on pupac }\end{array}$ & $\begin{array}{c}\text { New } \\
\text { females }\end{array}$ & $\begin{array}{c}\text { Female } \\
\text { Deuto- } \\
\text { nymphs }\end{array}$ & $\begin{array}{c}\text { Female } \\
\text { Proto- } \\
\text { nymphs } \\
\text { or males }\end{array}$ & Eggs \\
\cline { 2 - 8 } $\begin{array}{l}\text { Worker } \\
\text { brood } \\
\begin{array}{l}\text { Drone } \\
\text { brood }\end{array}\end{array}$ & 1320 & 3 & 2 & 2 & 0 & 1 & 1 & 1 \\
\hline \hline
\end{tabular}

\section{DISCUSSION}

It is clearly demonstrated that Varroa jacobsoni can reproduce in both worker and drone cells of Apis cerana, though there is a preference for drone brood.

Mite progeny which have attained the deutonymphal stage on a worker pupa can be expected to attain the adult phase by the time the bee emerges. Therefore their appearance signifies an effective reproduction.

The supposed recent adaptation of Varroa jacobsoni for reproduction on Apis mellifera worker brood had apparently already occurred on the original host, Apis cerana. 


\section{ACKNOWLEDGEMENTS}

The observations were made while the author visited South Korea as a consultant for FAO (Food and Agriculture Organization of the United Nations). Ana Lucia de Grava Kempinas assisted in the collections. The author also thanks Professors Y.H. Chiang, Hang Kyun Park, and Young Eoun Chol of the Bee Laboratory of the Institute of Agriculture Science and Technology, Kyungpook National University, in Taegu, South Korea, and M. Myeong Lyeol Lee and Prof. Seung Yoon Chol of the Apiculture Research section of Seoul National University in Suweon for assisting in the localization of and access to Apis cerana colonics.

\section{RÉSUMÉ}

\section{REPRODUCTION DE VARROA JACOBSONI DANS DES CELLULES D'OUVRIËRES D'APIS CERANA EN CORÉE DU SUD}

Contrairement aux informations venant de Sri Lanka et d'Indonésie concernant l'incapacité de Varroa jacobsoni à se reproduire sur le couvain d'ouvrières de son hôte primitif Apis cerana, on a trouvé en Corée du Sud des colonies d'Apis cerana, dans lesquelles l'acarien se reproduisait dans des cellules d'ouvrière.

\section{ZUSAMMENFASSUNG}

\section{IN SÜDKOREA VERMEHRT SICH VARROA JACOBSONI AUCH IN ARBEITERINNENZELLEN VON APIS CERANA}

Im Gegensatz zu früheren Meldungen aus Sri Lanka und Indonesien über die Unfähigkeit der Milbe Varroa jacobsoni, sich auf Arbeiterinnenbrut ihres ursprünglichen Wirts, Apis cerana, zu vermehren, konnten wir nun in Südkorea die erfolgreiche Reproduktion der Milbe in Arbeiterinnenzellen von Apis cerana nachweisen.

\section{BIBLIOGRAPHY}

DE Jong D. Morse R.A. Eickwort G.C., 1982. - Mite pests of honey bees. Annu. Rev., Entomol., 27, 229-252.

Koeniger N. Koeniger G. Wijayagunasekara N.H.P., 1981. - Beobachtungen über die Anpassung von Varroa jacobsoni an ihren natürlichen Wirt Apis cerana in Sri Lanka. (Observations on the adaptation of Varroa jacobsoni to its natural host Apis cerana in Sri Lanka). Apidologie, 12, 37-40.

Koeniger N. Koeniger G. Delfinado-Baker M., 1983. - Observations on mites of the Asian honeybee species (Apis cerana, Apis dorsata, Apis florea). Apidologie, 14, 197-204.

Peng Y.S.C., Fang Y, Xu S, Ge L., 1987. - The resistance mechanism of the Asian honey bee, Apis cerana Fabr., to an ectoparasitic mite. Varroa jacobsoni Oudemans. J. Invertebr. Pathol., 49, 54-60. 